\title{
PEMBELAJARAN SEJARAH DALAM MENGEMBANGKAN GREEN BEHAVIOR PESERTA DIDIK MELALUI NILAI-NILAI KEARIPAN LOKAL HUTAN LINDUNG SITU LENGKONG PANJALU Oleh:

\author{
Wulan Sondarika ${ }^{1)}$, Dewi Ratih ${ }^{2)}$ \\ ${ }^{1,2)}$ Dosen Prodi. Pendidikan Sejarah Unigal \\ ${ }^{1)}$ E-mail: wulansondarika13@gmail.com; ${ }^{2)}$ E-mail: ratihdewi231@gmail.com
}

\begin{abstract}
ABSTRAK
Penelitian ini berjudul "Pembelajaran Sejarah Dalam Mengembangkan Green Behavior Peserta Didik Melalui Nilai-Nilai Kearipan Lokal Hutan Lindung Situ Lengkong Panjalu Kabupaten Ciamis Jawa Barat". Teknik pengumpulan data yaitu dengan wawancara, observasi dan studi dokumentasi. Hasil dari penelitian ini menunjukkan relevansi nilai-nilai kearifan lokal hutan lindung Situ Lengkong yang berkaitan dengan pengembangan Green Behavior dapat di internalisasikan dalam pembelajaran sejarah di SMKN I Panjalu.
\end{abstract}

Kata kunci: Pembelajaran Sejarah, Nilai-nilai Kearifan Lokal, Green Behavior

\section{PENDAHULUAN}

Hutan adalah suatu kumpulan atau asosiasi pohon-pohon yang cukup rapat dan menutup areal yang cukup puas sehingga akan dapat membentuk iklim mikro yang kondisi ekologis yang khas serta berbeda dengan areal luarnya.

Alasan penulis menjadikan SMKN 1 Panjalu sebagai tempat penelitian karena SMKN 1 Panjalu sekolah yang terdekat dengan fokus penelitian yaitu Hutan Larangan atau Hutan Lindung Situ Lengkong Panjalu yang dilindungi dengan berbagai larangan atau dengan berbagai tabu. Hutan lindung ini bagi masyarakat Panjalu bukan sekedar hutan biasa, hutan ini yang dianggap keramat/dikeramatkan oleh karena itu generasi muda atau peserta didik harus memahami sejarah dan nilai kearifan lokal keberadaan hutan lindung Situ Lengkong yang sarat dengan kesejarahnnya yang harus diketahui, dipahami dan dijaga oleh selurus masyarakat termasuk para peserta didik.

Dengan memasukkan masalah hutan lindung dan green behavior dalam materi pembelajaran sejarah, hal ini menjadikan mata pelajaran sejarah lebih menarik dan berfariatif sehingga menepis asumsi masyarakat bahwa pelajaran sejarah itu monotan dan membosankan karena biasanya pembelajaran sejarah hanya dilakukan di dalam kelas dan pembahasannya yang ada di dalam buku teks pelajaran saja.

Materi pembelajaran sejarah yang memasukkan hutan lindung Situ Lengkong dan green behavior dapat menggiring peserta didik untuk berfikir kritis sehingga mampu memahami dan mengetahui nilai-nilai kearifan lokal yang terdapat di hutan lindung Situ Lengkong adalah merupakan pewarisan sejarah. Peserta didik sebagai generasi penerus yang hidup dalam kurun waktu sekarang dan masa yang akan datang dengan masalah-masalah yang berbeda tentu tidak begitu saja akan menerima warisan itu. Menurut Saini (2004: 27-28), bahwa

Volume 6, 2, Agustus 2019| 24 
mereka akan melakukan pemilihan dan pengolahan kembali nilai-nilai yang diwariskan dan mengambil yang menurutnya paling cocok serta sesuai dengan kepentingan keselamatan dan kesejahteraan generasi berikut. Seleksi tersebut akan terjadi dengan baik melalui pembelajaran dengan menggunakan sumber belajar yang bermakana.

Pendidikan mesti mampu mengubah paradigmanya dari yang fragmented menjadi pendekatan ekologis yang menempatkan pendidikan dalam sebuah konteks lingkungan yang saling terkait (ecological approach). Terjadinya berbagai bencana kerusakan di lingkungan semesta diakibatkan ulah tangan, pikir, dan hati manusia telah disadarkan bahwa pendidikan mesti mampu mewujudkan keseimbangan antara kehidupan manusia di alam semesta ini. Masalah lingkungan dan konservasi merupakan masalah luar biasa oleh karena terkait dengan pendidikan individu yang butuh dipraktikkan.

Berdasarkan observasi yang dilakukan oleh peneliti di SMKN 1 Panajalu sebenarnya telah mengembangkan upaya penghijauan di lingkungan sekolah dengan memanfaatkan lahan produktif untuk menanam, karena warga sekolah menyadari fenomena lingkungan yang semakin hari semakin rusak sehingga peserta didik harus peduli terhadap lingkungan sekitar. SMKN 1 Panjalu yang berlokasi di wilayah Panjalu Ciamis, tentunya memiliki potensi untuk memanfaatkan kondisi geografis wilayah setempat yang dekat dengan hutan lindung Situ Lengkong. Selain sebagai hutan lindung, hutan tersebut pun memiliki nilai sejarah yang berarti bagi masyarakat Panjalu, oleh karena itu keberadaan hutan lindung Situ Lengkong dapat dijadikan sumber belajar khususnya dalam pembelajaran sejarah. Salah satu upaya untuk mengembangkan green behavior peserta didik terutama dalam pembelajaran sejarah di sekolah adalah salah satunya dengan memanfaatkan hutan lindung yang ada di lingkungan sekitar para peserta didik. Untuk meningkatkan respon dan minat peserta didik terhadap pelajaran sejarah adalah dengan menciptakan pola pembelajaran yang terkait dengan situasi lingkungannya.

\section{METODE PENELITIAN}

Penelitian tentang pemanfaatan hutan lindung dalam mengembangkan green behavior peserta didik melalui pembelajaran sejarah ini menggunakan pendekatan kualitatif dengan metode penelitian kualitatif interaktif yang ditujukan untuk mendeskripsikan dan menganalisis fenomena, peristiwa, aktivitas sosial,sikap, kepercayaan, persepsi, pemikiran orang secara individual maupun kelompok. Penelitian kualitatif mempunyai dua tujuan utama, yaitu :pertama, menggambarkan dan mengungkap (to describe and explore) dan kedua menggambarkan dan menjelaskan (describe to explain).

\section{HASIL PENELITIAN DAN PEMBAHASAN \\ Deskripsi Lokasi Penelitian}

SMKN 1 Panjalu terletak di Jl. Hujungtiwu Kecamatan Panjalu Kabupaten Ciamis. Berstatus Negeri dan SMKN I Panjalu ini sudah mandiri. SMKN I Panjalu ini adalah peralihan dari SMAN I Panjalu pada tahun 2014 yang dikepalai 
oleh bapak Drs. Hadi Sumantoro., M.Pd. Adapun data selengkapnya SMKN I Panjalu sebagai berikut:

1. Jurusan ATPH untuk kelas $X$ berjumlah 11 siswa terdiri dari berjenis kelamin laki-laki. Kelas XI berjumlah 14 siswa terdiri dari 2 laki-laki dan 12 perempuan. Jumlah keseluruhan jurusan ATPH yaitu 25 siswa.

2. Jurusan TKJ untuk kelas $X$ berjumlah 55 siswa terdiri dari 27 laki-laki dan 28 perempuan. Kelas XI berjumlah 31 siswa terdiri dari 7 laki-laki dan 24 perempuan. Jumlah keseluruhan jurusan TKJ yaitu 86 siswa.

3. Jurusan TKR untuk kelas $\mathrm{X}$ berjumlah 31 siswa terdiri dari 31 laki-laki. Kela XI berjumlah 25 siswa terdiri dari 22 laki-laki dan 3 perempuan. Jumlah keseluruhan jurusan TKR 56 siswa.

\section{HASIL PENELITIAN DAN PEMBAHASAN}

\section{Hasil Penelitian}

\section{Nilai-Nilai Kearifan Lokal di Hutan Lindung Situ Lengkong yang berkaitan dengan Green Behavior}

Berdasarkan observasi peneliti di hutan lindung Situ Lengkong, peneliti melihat kondisi kawasan hutan lindung Siti Lengkong terdapat nilai-nilai kearifan lokal yang berkaitan dengan green behavior. Di hutan lindung Situ Lengkong terdapat nilai keindahan yaitu letak hutan lindung Situ lengkong tepat berada di tengah danau, dan banyak terdapat berbagai jenis pohon yang rindang sehingga udara di sekitar Situ Lengkong sangat sejuk dan asri, dari hal tersebut sangat mengurangi polusi udara sehingga daerah sekitar menjadi sehat dan bersih. Hutan lindung Situ Lengkong ini dibentengi dengan air danau sehingga akses untuk menuju hutan itu agak sulit sehingga terhindar dari penjarahan atau pembalakan hutan. Artinya dari nilai-nilai di atas yaitu nilai keindahan, nilai kesehatan, nilai kesejukkan, dan nilai kelestarian akan mewujudkan kesimbangan ekosistem.

Untuk memperoleh data yang valid, maka peneliti melakukan observasi kepada guru mata pelajaran sejarah di SMKN I Panjalu yaitu Bapak Ohim Hadia yang memasukkan materi sejarah lokal dalam pembelajaran sejarah di kelas $\mathrm{X}$ dengan memanfaatkan nilai-nilai kearifan lokal yang berkaitan dengan green behavior hutan lindung Situ Lengkong. Peneliti melakukan observasi berdasarkan beberapa aspek yang akan diteliti, peneliti mengajukan beberapa pertanyaan kepada guru sejarah, "bagaimana cara bapak mendesain pembelajaran sejarah yang dikaitan dengan green behavior?", Guru sejarah yang bernama bapak Ohim menjawab, "dalam pembelajaran sejarah lokal saya telah mendesain sesuai dengan silabus pelajaran sejarah yang berpedoman kepada KTSP di kelas X SMKN I Panjalu, RPP dengan indikator-indikator, tujuan pembelajaran sejarah, materi pembelajaran, pendekatan, strategi dan metode pembelajaran, evaluasi pembelajaran dan tindak lanjut pembelajaran seperti remedial dan pengayaan". Pertanyaan peneliti selanjutnya kepada guru pelajaran sejarah "bagaimana cara bapak mendesain RPP sejarah lokal yang sesuai dengan nilai-nilai kearifan lokal?", kemudian guru sejarah menjawab, "saya memasukkan keterkaitan silabus dengan KTSP pada pelajaran Sejarah kelas X semester satu di satuan pendidikan SMK dengan KI "Menghayati dan mengamalkan perilaku jujur, disiplin, tanggung jawab, peduli (gotong royong, kerja sama, toleran, damai), santun, responsif dan pro aktif dan menunjukkan sikap sebagai bagian dari solusi atas

Volume 6, 2, Agustus 2019| 26 
berbagai permasalahan dalam berinteraksi secara efektif dengan lingkungan sosial dan alam serta dalam dalam menempatkan diri sebagai cerminan bangsa dalam pergaulan dunia.". Sedangkan KD-nya adalah: "Menganalisis berdasarkan tipologi hasil budaya pra aksara Indonesia termasuk yang berada di lingkungan terdekat". Pertanyaan peneliti selanjutnya, "bagaimana kemampuan guru mendesain metode pembelajaran sejarah lokal yang sesuai dengan materi pembelajaran?", kemudian guru sejarah menjawab, "dalam pembelajaran saya menggunakan metode diskusi yang dipadukan dengan metode lain seperti ceramah, tanya jawab, pemberian tugas, brainstorming dan pengalaman lapangan".

\section{Pelaksanaan Pembelajaran Sejarah di SMKN I Panjalu dalam Mengembangkan Green Behavior Peserta Didik dengan Memanfaatkan Hutan Lindung Situ Lengkong}

Berdasarkan hasil observasi pertama dilakukan pada tanggal 14 Nopember 2014, dengan metode ceramah, guru melakukan interprestasi sendiri terhadap materi pelajaran, baik dalam (SK) standar kompetensi maupun (KD) kompetensi dasar. Pada penelitian pertama yang dilakukan di kelas X TKJ II SMKN I Panjalu, peneliti mengamati guru mata pelajaran sejarah yang sudah melakukan upayaupaya untuk mengembangkan nilai-nilai kearifan lokal hutan lindung Situ Lengkong dalam mengembangkan green behavior peserta didik melalui pembelaajaran sejarah.

Pembelajaran di kelas guru menyampaikan materi pelajaran dengan menggunakan silabus yang berpedoman pada (RPP) Rencana Pelaksanaan Pembelajaran yang sudah dibuatnya dengan Kompetensi Inti (KI) "Menghayati dan mengamalkan perilaku jujur, disiplin, tanggung jawab, peduli (gotong royong, kerja sama, toleran, damai), santun, responsif dan pro aktif dan menunjukkan sikap sebagai bagian dari solusi atas berbagai permasalahan dalam berinteraksi secara efektif dengan lingkungan sosial dan alam serta dalam dalam menempatkan diri sebagai cerminan bangsa dalam pergaulan dunia.". Sedangkan KD-nya adalah: "Menganalisis berdasarkan tipologi hasil budaya pra aksara Indonesia termasuk yang berada di lingkungan terdekat". Proses belajar mengajar (PBM) di kelas X TKJ II, guru menggunakan metode ceramah yang divariasikan dengan tanya jawab, dan juga menggunakan alat bantu power point sebagai rangkuman materi yang akan disampaikan, dan siswa juga menggunakan buku teks pelajaran sejarah untuk memudahkan siswa dalam memahami materi yang sedang dibahas. Pada saat memulai pembelajaran guru menyuruh ketua kelas memimpin doa, kemudian guru menyuruh siswa untuk tadarusan, setelah itu guru mengingatkan jangan ada aktifitas lain selain kegiatan belajar. Setelah apersepsi guru bertanya tentang pengaruh kebudayaan Hindu-Budha terhadap kebudayaan Indonesia, siswa yang bernama Rita menjawab ini seperti adanya upacara adat diantaranya Galungan, Nyangku, kemudian siswa bernama Dapit menambahkan adanya upacara keagamaan seperti empat bulanan kehamilan, Maulid Nabi, Isra Mi'raj, dan sebagainya. Kemudian guru bertanya lagi bagaimana agama yang dianut pada masa itu, siswa bernama Sela menjawab pada masa itu banyak kepercayaankepercayaan yang dianut masyarakat seperti percaya terhadap roh nenek moyang, kepercayaan Animisme dan Dinamisme. 
Guru menjelaskan bahwa pada masa Hindu-Budha memang banyak kepercayaan-keprcayaan yang dianut, misalnya Animisme dan dinamisme. Guru bertanya apa Animisme itu, hampir semua siswa menjawab percaya terhadap roh nenek moyang. Kemudian guru bertanya kalau Dinamisme itu apa, siswa yang bernama Sela menjawab percaya terhadap benda-benda. Guru bertanya bendanya itu apa saja, beberapa siswa menjawab, keris, batu, pohon, tempat-tempat keramat. Dari jawaban anak-anak tersebut guru kemudian menjelaskan tentang tempat dan pohon-pohon yang dikeramatkan yaitu tempat dan pohon-pohon yang harus dihormati dan tidak sembarang orang boleh kesana karena adanya laranganlarangan atau hal-hal tabu yang tidak boleh dilanggar. Karena kalau melanggranya akan mendapat tulah atau akibat atau bencana. Guru menjelaskan bahwa di daerah dekat siswa juga adat tempat-tempat yang dikeramatkan, kemudian memberikan pertanyaan siapa yang tahu dimana tempat itu, siswa yang bernama Indra menjawab di Panjalu, Pak. Guru bertanya lagi ya dimana tempatnya?, di Situ Lengkong. Dari jawaban siswa yang bernama Indra, kemudian guru menjelaskan bahwa situs keramat alami dapat dalam status legal sebagai kawasan konservasi atau dapat juga diluar sistem formal. Salah satu contoh yang menarik adalah Situ Lengkong di Kabupaten Ciamis, Jawa Barat. Pulau kecil di tengah situ tersebut dikeramatkan oleh penduduk sesitus dan dinamai Nusa Gede, Nusa Panjalu, atau Nusalarang. Pada zaman penjajahan Belanda, "pulau" kecil tersebut diberi nama Pulau Koorders sebagai penghargaan kepada Dr Koorders, pendiri dan ketua pertama Nederlandsch Indische Vereeniging tot Natuurbescherming (perkumpulan perlindungan alam Hindia Belanda) yang didirikan pada tahun 1863. Sejak tanggal 21 Februari 1919 kawasan tersebut resmi dilindungi dengan undang-undang dengan status cagar alam sampai jaman Republik Indonesia sekarang. Selanjutnya pada akhir pembelajaran (penutup), guru dan siswa menarik kesimpulan, agar kita sebagai generasi penerus bangsa, terutama peserta didik yang merupakan golongan terpelajar diharapkan dapat memiliki sikap kepedulian terhadap lingkungan dengan selalu menanamkan prilaku hijau atau disebut juga green behavior.

Observasi kedua yaitu pada tanggal 28 Nopember 2014, setelah bel masuk berbunyi, guru mata pelajar sejarah bersiap-siap untuk ke kelas X TKJ II, karena pada hari ini mata pelajaran sejarah di mulai pada jam pertama. Pada awal masuk kelas, guru mengucapkan salam dan siswa menjawabnya. Kemudian guru mempersilakan ketua kelas untuk memimpin do'a sebelum aktivitas belajar dimulai dan melanjutkan dengan tadarus surat Al Quraiys. Setelah pembacaan tadarus, guru menanyakan kabar semua siswa dan mengabsen siswa satu per satu. Pada bagian ini pula, guru mengingatkan agar pada saat pembelajaran berlangsung siswa dilarang melakukan aktivitas lain diluar pembelajaran.

Sebelum Proses Belajar Mengajar (PBM) berlangsung, Guru mata pelajaran sejaran sudah mempersiapkan RPP dan buku paket sebagai pedoman dalam melaksanakan pembelajaran sejarah di kelas. Pada observasi kedua ini peneliti memperhatikan persiapan materi, pada saat pembelajaran sejarah guru menyajikan materi pembelajaran berdasarkan pada Kompetensi Inti (KI) "Menghayati dan mengamalkan perilaku jujur, disiplin, tanggung jawab, peduli (gotong royong, kerja sama, toleran, damai), santun, responsif dan pro aktif dan menunjukkan sikap sebagai bagian dari solusi atas berbagai permasalahan dalam berinteraksi

Volume 6, 2, Agustus 2019 | 28 
secara efektif dengan lingkungan sosial dan alam serta dalam dalam menempatkan diri sebagai cerminan bangsa dalam pergaulan dunia".

Pada bagian selanjutnya yaitu apersepsi, guru bertanya pada siswa tentang materi yang sudah disampaikan pada minggu yang lalu, yakni tentang kehidupan masyarakat zaman pra aksara, pesebaran asal-usul nenek moyang bangsa Indonesia dan peninggalan hasil-hasil kebudayaan pada zaman pra aksara. Salah seorang siswa mengacungkan tangan untuk mendeskripsikan tentang materi tersebut. Kemudian guru menyampaikan materi yang akan dipelajari pada pertemuan hari itu. Untuk mengkonsentrasikan perhatian siswa, guru bertanya:" Kerajaan-kerajaan apa saja yang ada di Indonesia pada masa Hindu-Budha?, sejenak siswa terdiam, sampai akhirnya salah seorang siswa yang bernama Lidia menjawab, kerajaan Majapahit dan Kerajaan Pajajaran, Pak. Kemudian guru bertanya: Siapa Raja Pajajaran yang kalian tahu?, siswa yang bernama Siti Kartika menjawab Sri Baduga, Pak. Kemudian guru menambahkan nama Raja Pajajaran lain yang bernama Niskala Wastukancana.

Pada tahap elaborasi, guru memberikan tugas pada siswa untuk menganalisis berbagai fakta yang ada yang berkaitan dengan kerajaan-kerajaan yang bercorak Hindu-Budha, termasuk Kerajaan Pajajaran dalam bentuk tabel. Dalam mengerjakan tugas tersebut, siswa diperbolehkan untuk mencari bahanbahan dari berbagai buku sumber yang tersedia di perpustakaan dan internet yang sudah disediakan sekolah. Setelah pekerjaan siswa selesai, guru kemudian meminta beberapa perwakilan siswa maju ke depan dan mempresentasikan hasil temuannya. Pada sesi ini, dibuka forum tanya jawab untuk menampung pertanyaan dan respon siswa, baik berupa tanggapan ataupun sanggahan. Satu per satu perwakilan siswa mengemukakan hasil temuannya dari mulai Kutai, Tarumanagara, Sriwijaya, Holing, Mataram, Kediri, Singasari, Majapahit, Bali sampai Pajajaran.

Pada tahap tahap selanjutnya yaitu tahap konfirmasi, guru mengklarifikasi berbagai temuan fakta yang berkaitan dengan kerajaan-kerajaan yang bercorak Hindu-Budha, misalnya mengenai kearifan lokal yang merupakan warisan sejarah dan budaya yang dipengaruhi oleh kerajaan-kerajaan Hindu-Budha terutama dari Kerajaan Pajajaran yang mempengaruhi prilaku dan budaya masyarakat Sunda secara umum, termasuk lingkungan dimana peserta didik tinggal. Pada bagian ini, guru menggunakan metode tanya jawab dengan siswa tentang warisan sejarah dan budaya dari Kerajaan Pajajaran yang masih dipegang teguh oleh masyarakat, misalnya tentang kearifan lokal yang berkaitan dengan pelestarian lingkungan. Siswa bernama Adris mendeskripsikan tentang kelanjutan materi sebelumnya yang berkaitan dengan keberadaan situs Situ Lengkong yang memiliki makna penting bagi masyarakat Panjalu, terutama dalam hal keberlangsungan lingkungan hidup. Guru kemudian mengklarifikasi, dengan menghubungkan cerita-cerita rakyat yang berada di sekitar Situ Lengkong yang berorientasi pada kearifan lokal tentang lingkungan.

Pada tahap penutup, guru mengakhiri pelajaran dengan memberikan informasi materi dan tugas berikutnya, yakni rencana untuk melakukan kunjungan wisata ke Hutan lindung Situ lengkong.

Observasi ketiga dilaksanakan pada hari minggu karena akan berkunjung ke Situ Lengkong yaitu pada tanggal 7 Desember 2014 sesuai dengan rencana

Volume 6, 2, Agustus 2019 | 29 
sebelumnya, siswa didampingi guru sejarah akan melakukan kunjungan wisata ke hutan lindung Situ lengkong.

Setelah sampai di area hutan lindung Situ Lengkong, siswa bergabung dengan anggota kelompoknya untuk segera melakukan mengamati kondisi hutan lindung Situ Lengkong dengan mewawancarai narasumber yaitu kuncen, petugas kehutanan dan masyarakat sekitar. Hal yang menjadi fokus pembelajaran mereka berkaitan dengan sejarah hutan lindung Situ Lengkong, fungsi hutan bagi masyarakat dan keberlangsungan ekosistem, makna hutan bagi masyarakat sekitar, dan aktivitas terencana yang dilakukan dalam rangka menjaga kelestarian hutan lindung Situ Lengkong.

Setelah siswa selesai mengamati dan mewawancarai narasumber, siswa diajak untuk menanam tanaman sebagai pengganti pohon-pohon yang sudah tumbang dan berumur tua. Setelah kegiatan menanam pohon siswa melakukan operasi semut (bersih-bersih), terhadap sampah-sampah bekas pengunjung. Setelah itu kegiatan dilajutkan dengan acara makan siang dilanjutkan ramah tamah dengan petugas dari kehutanan (polisi hutan) dan kuncen. Dalam acara ramah tamah itu, terjadi dialog antara siswa, guru, kuncen dan petugas hutan terutama berkaitan dengan makna dibalik hal-hal yang dianggap tabu dan mitos tentang perlindungan terhadap hutan tersebut. Dalam dialog itu terungkap kesimpulan dari siswa bahwa dilihat dari sisi historis tentang keberadaan hutan itu memiliki makna yang strategis dalam pelestarian lingkungan. Disamping itu mitos masyarakat dan hal-hal yang bersifat tabu sesungguhnya berorientasi semata-mata untuk menjaga hutan agar tetap lestari dan terjaga ekosistemnya.

Setelah sholat dzuhur rombongan pulang kembali ke sekolah. Setelah sampai di sekolah guru mengingatkan siswa untuk membuat laporan hasil kunjungan wisata ke Hutan Lindung Situ Lengkong tersebut.

Observasi keempat tanggal 19 Desember 2014 pada kesempatan ini materi yang dibahas mengenai hasil kunjungan ke Hutan Lindung Situ Lengkong. Pada bagian awal, ketika masuk kelas, Guru mengucap salam dan menanyakan kabar para siswa, semua siswa menjawab salam "waalaikum salam, baik pa". Kemudian guru mempersilakan ketua kelas untuk memimpin do'a sebelum aktivitas belajar dimulai. Dalam mengawali pembelajaran guru dan siswa berdoa menurut agama dan kepercayaan masing-masing, dan melanjutkan dengan tadarus surat Al Qurais. Setelah pembacaan tadarus, guru mengabsen siswa satu per satu siawa kelas $X$ TKJ II. Selanjutnya guru mengingatkan agar pada saat pembelajaran berlangsung siswa dilarang melakukan aktivitas lain diluar pembelajaran.

Pada bagian apersepsi, guru bertanya jawab dengan siswa mengenai materi sebelumnya. Dalam kesempatan itu guru bertanya: Apakah menurut kalian terdapat hubungan antara Kerajaan Pajajaran dengan hutan lindung Situ Lengkong? siswa yang bernama Yoga menjawab: sejak Kerajaan Sunda, Pajajaran dan Galuh berdiri, sudah memiliki kearifan-kearifan lokal, contohnya kepedulian terhadap lingkungan dengan cara yang berbeda-beda, seperti adanya hutan dan situ larangan.

Pada pembelajaran ini guru menggunakan metode diskusi, pada pertemuan ini semua kelompok secara bergiliran mempresentasikan hasil temuan dari kunjungan ke hutan lindung situ lengkong. Kelompok pertama yang diketuai oleh Yonan, maju kedepan untuk mempresentasikan laporan kelompoknya dengan

Volume 6, 2, Agustus 2019 | 30 
tema sejarah Hutan Lindung Situ Lengkong. Kelompok pertama yang diketuai oleh Indra ini menjelaskankan tentang sejarah Situ Lengkong, sebagai berikut:

Hutan lindung Situ Lengkong disebut juga Nusa Larang. Adapun asal mula Nusa Larang ini berhubungan dengan hal-hal yang di mistiskan sampai saat ini. Situ Lengkong sekarang termasuk ke dalam wilayah Desa/Kecamatan Panjalu Kabupaten Ciamis Jawa Barat. Dalam Bahasa Sunda; kata situ artinya danau. Situ Lengkong atau dikenal juga dengan Situ Panjalu terletak di ketinggian $700 \mathrm{~m}$ di atas permukaan laut. Di tengah danau tersebut terdapat sebuah pulau yang dinamai Nusa Larang atau Nusa Gede atau ada juga yang menyebutnya sebagai Nusa Panjalu. Menurut legenda rakyat dan Babad Panjalu, Situ Lengkong adalah sebuah danau buatan, sebelumnya daerah ini adalah kawasan legok (bhs. Sunda : lembah) yang mengelilingi bukit bernama Pasir Jambu (Bhs. Sunda: pasir artinya bukit).

Masyarakat Panjalu, khususnya di daerah sekitar Situ Lengkong memiliki sejarah atau lebih tepatnya disebut asal usul. Asal usul Hutan Larangan (Hutan Lindung Situ Lengkong) merupakan salah satu mitos yang berkembang dalam masyarakat Panjalu (Ciamis). Mitos tersebut bersumber pada tradisi lisan yang dituturkan secara turun temurun.

Setelah kelompok ini membacakan hasil laporanya, dibuka sesi tanya jawab untuk dua penanya dari kelompok lain. Pertanyaan pertama dari siswa Dida, pertanyaannya: mengapa pada zaman Belanda hutan tersebuat dijadikan cagar alam? Siswa yang bernama Leni menjawab: tujuan dibuat cagar alam untuk persediaan cadangan air bila musim kemarau tiba dan untuk mencegah terjadinya erosi. Pertanyaan kedua dari siswa yang bernama Amalia, pertanyaannya: mengapa Prabu Borosngora dimakamkan di nusa larang? Siswa Yayang menjawab: karenabu Borosngora adalah orang pertama yang membuka lahan hutan lindung situ lengkong.

Kelompok dua yang dipimpin oleh Santi Eliana menyajikan laporannya dengan tema Fungsi dan Makna Hutan Lindung. Adapun fungsi hutan lindung yaitu untuk menjaga keseimbangan alam, menjaga kelestarian lingkungan, menjaga beragam habitat yang ada di hutan. Makna dari penjagaan hutan antaralain yaitu agar masyarakat menyadari pentingnya pelestarian lingkungan sebagai upaya keberlangsungan ekosistem. Siswa yang bernama Puput bertanya: bagaimana masyarakat Panjalu menunjukkan kepeduliannya terhadap lingkungan? Lalu siswa yang bernama Wawan menjawab: masyarakat Panjalu menjaga hutan tersebut dengan cara tidak menebang pohon-pohon untuk dijadikan kayu bakar.

Kelompok tiga yang dipimpin oleh Resti Pajriah mempresentasikan mengenai tema mitos dan hal-hal yang dianggap tabu yang berkaitan dengan hutan lindung Situ Lengkong, seperti larangan menebang pohon, mengambil hasil hutan, berbicara sembarangan, dan berperilaku tidak senonoh, jika semua tabu itu dilanggar maka siapapun akan mendapatkan malapetaka. Apabila melakukan penebangan pohon oleh banyak orang akan menimbulkan bencana bagi masyarakat. Selanjutnya kelompok ini membahas tentang adanya mitos hutan lindung Situ Lengkong yang dipercaya oleh masyarakat setempat bahwa hutan tersebut aya nu ngageugeuh (ada yang menjaga) yaitu seekor naga, konon bila ada yang mengganggu ketenangan atau merusak hutan maka naga tersebut akan keluar dan marah. Kemudian kelompok tiga bertanya yang diwakili oleh siswa yang

Volume 6, 2, Agustus 2019| 31 
bernama Yosi: mengapa mitos-mitos dan hal tabu tersebut masih dipertahankan hingga sekarang? Lalu kelompok penyaji yang diwakili oleh siswa yang bernama Andri menjawab: karena mitos tersebut sudah turun temurun dan diyakini oleh masyarakat sebagai hal yang harus ditaati, begitupula dengan berbagai hal tabu yang masih dipegang teguh karena bila dilanggar masyarakat takut akan akibat atau malapetaka yang akan menimpanya.

\section{Pembahasan}

1. Analisis terhadap Nilai-nilai Kearifan Lokal yang berkaitan dengan Green Behavior di Hutan Lindung Situ Lengkong

Observasi yang dilaksakan secara langsung oleh peneliti dalam mengamati nilai-nilai kearifan lokal hutan lindung Situ Lengkong yang berkaitan dengan pengembangan green behavior siswa di SMKN I Panjalu, mengahasilkan asumsi bahwa dari lingkungan sekitar siswa dapat dijadikan bahan ajar dalam mata pelajaran sejarah, contohnya yaitu hutan lindung Situ Lengkong yang syarat dengan kesejarahan yang mengandung nilai-nilai kearifan lokal yang berkaitan dengan green behavior.

Tabel 1. Hubungan Nilai-nilai Kearifan Lokal Hutan Lindung Situ Lengkong dengan Materi Pembelajaran Sejarah

\begin{tabular}{|c|c|c|c|}
\hline Materi Pembelajaran & $\begin{array}{l}\text { Hutan Lindung } \\
\text { Situ Lengkong }\end{array}$ & Kearifan Lokal & $\begin{array}{c}\text { Interpretasi dan } \\
\text { pengembangan green } \\
\text { behavior }\end{array}$ \\
\hline \multirow[t]{4}{*}{$\begin{array}{l}\text { - Kerajaan-kerajaan } \\
\text { Hindu-Budha di } \\
\text { Indonesia } \\
\text { - Runtuhnya tradisi } \\
\text { Hindu-Budha di } \\
\text { Indonesia }\end{array}$} & $\begin{array}{l}\text { - Hutan Larangan } \\
\text { - Makam Leluhur }\end{array}$ & $\begin{array}{l}\text { - amanat leluhur untuk } \\
\text { dijaga dan dilestarikan. } \\
\text { - ekplorasi pada hutan } \\
\text { larangan dibatasi } \\
\text { (sebagai bentuk nilai } \\
\text { kelestarian). }\end{array}$ & \multirow{4}{*}{$\begin{array}{l}\text { Warisan sejarah dan budaya } \\
\text { dari Kerajaan Pajajaran yang } \\
\text { masih dipegang teguh oleh } \\
\text { masyarakat, misalnya tentang } \\
\text { kearifan lokal yang berkaitan } \\
\text { dengan pelestarian } \\
\text { lingkungan } \\
\text { Contoh: Raja Purnawarman } \\
\text { sebagai raja Tarumanegara } \\
\text { telah memiliki pandangan } \\
\text { tentang kepedulian terhadap } \\
\text { lingkungan seperti membuat } \\
\text { saluran gomati supaya } \\
\text { terhindar dari bahaya } \\
\text { bencana banjir, hal ini } \\
\text { tercantum dalam Prasasti } \\
\text { Tugu. Apa yang telah } \\
\text { dilakukan oleh Purnawarman } \\
\text { tersebut dijadikan tolak ukur } \\
\text { oleh penerus kerajaan } \\
\text { Pajajaran berikutnya } \\
\text { termasuk di Ciamis sebagai } \\
\text { bagian dari kerajaan Sunda } \\
\text { atau Pajajaran. }\end{array}$} \\
\hline & $\begin{array}{l}\text { Ada larangan (aturan } \\
\text { secara lisan) pamali, } \\
\text { tabu. Seperti } \\
\text { Larangan tata laku } \\
\text { ketika di hutan }\end{array}$ & $\begin{array}{l}\text { Nilai pelestarian } \\
\text { lingkungan }\end{array}$ & \\
\hline & $\begin{array}{l}\text { Letak hutan lindung } \\
\text { Situ Lengkong yang } \\
\text { strategis. Hutan } \\
\text { dibentengi oleh air } \\
\text { danau. }\end{array}$ & $\begin{array}{l}\text { Kearifan lokal yang } \\
\text { berkaitan dengan nilai } \\
\text { keindahan. }\end{array}$ & \\
\hline & $\begin{array}{l}\text { Potensi hutan } \\
\text { (berbagai jenis } \\
\text { tumbuhan menutupi } \\
\text { lahan, sebagai lahan } \\
\text { cadangan air, adanya } \\
\text { keanekaragaman } \\
\text { hayati, kestabilan } \\
\text { cuaca dan iklim). }\end{array}$ & $\begin{array}{l}\text { Nilai ekologis yang } \\
\text { berkaitan dengan } \\
\text { kesehatan dan } \\
\text { kesejukan serta nilai } \\
\text { keseimbangan. }\end{array}$ & \\
\hline
\end{tabular}

Nilai-nilai kearifan lokal yang terdapat di hutan lindung Situ Lengkong, seperti melihat letak hutan yang berada di tengah-tengah danau tersebut terlihat sangat indah, ini merupakan nilai keindahan yang terdapat di hutan lindung Situ 
Lengkong yang dapat di ajarkan kepada peserta didik. Dengan melihat letak atau keberadaan hutan Situ Lengkong yang dibentengi dengan air danau sehingga akses untuk menuju hutan itu agak sulit sehingga terhindar dari penjarahan atau pembalakan hutan.

Nilai-nilai kearifan lokal lainnya yang peneliti temukan adalah di hutan situ lengkong terdapat hal-hal tabu yang masih dipegang teguh oleh masyarakat Panjalu, seperti adanya larangan mengambil kayu bakar dan menebang pohon di hutan tersebut, ini menjadikan hutan tetap terjaga kelestariannya, karena dengan adanya hal-hal tabu dan mitos itu tidak sembarang orang bisa memasuki hutan, tidak bisa menebang pohon-pohon di hutan itu masyarakat sangat mentaati hal-hal tabu tersebut karena takut kalau melanggar hal tabu itu akan mendatangankan bala atau malapetaka pada dirinya. Dengan demikian hutan lindung Situ Lengkong terhindar dari pembabakan dan penjarahan, ini merupakan nilai kelestarian yang ada pada hutan lindung Situ Lengkong.

Sejalan dengan pendapat Sutarto (2006:1) menyebutkan kearifan lokal atau kecendekiaan lokal (adat) yang digunakan sebagai pedoman dalam kehidupan bermasyarakat merupakan bagian sentral tradisi. Lebih lanjut Sutarto menjelaskan bahwa tradisi adalah kebiasaan turun-temurun yang mencerminkan keberadaban para pendukungnya. Tradisi lokal memperlihatkan bagaimana anggota masyarakat bertingkah laku, baik dalam kehidupan bersifat duniawi maupun gaib serta kehidupan keagamaan. Kearifan lokal ini yang merupakan tradisi mengatur bagaimana manusia berhubungan dengan manusia lainnya, dan bagaimana manusia memperlakukan lingkungannya.

Mutakin $(2005 ; 43)$ berpendapat bahwa kearifan lokal merupakan sebuah identitas masyarakat lokal yang penuh nilai-nilai sebagai pedoman, penuntun hidup masyarakat, yakni:Kemampuan berfikir, berasa, bersikap dan bertindak seseorang atau kelompok orang dalam upaya memperkenalkan dan menanam ide, konsep, gagasan, harapan, anjuran atau sejumlah informasi yang berkenaan dengan nilai-nilai dan norma-norma sebagai acuan tentang bagaimana selayaknya hidup dan kehidupan dikembangkan, dinikmati sehingga bermakna dan bermanfaat bagi individu yang bersangkutan serta lingkungannya.

Kearifan lokal masyarakat Panjalu yang memiliki orientasi terhadap masalah lingkungan sudah terbukti secara historis. Hal tersebut tercermin dalam tradisi dan mitos-mitos yang dimaknai oleh masyarakat Panjalu sebagai upaya untuk melestarikan lingkungan dalam rangka suistainable development. Berkaitan dengan penjagaan kelestarian hutan lindung Situ Lengkong ada hal-hal tabu yang ditaati oleh masyarakat setempat seperti larangan menebang pohon, mengambil hasil hutan, berbicara sembarangan, dan berperilaku tidak senonoh, jika semua tabu itu dilanggar maka siapapun akan mendapatkan malapetaka. Bahkan jika penebangan pohon dilakukan oleh banyak orang akan menimbulkan bencana bagi masyarakat.

Jika kita mencermati beberapa larangan (tabu) dalam masyarakat tersebut, nampak bahwa pewarisan nilai-nilai sejarah yang berorientasi kearifan lokal lingkungan sudah berlangsung dari masa ke masa. Adapula mitos mengenai hutan lindung Situ Lengkong yang dipercaya oleh masyarakat setempat bahwa hutan

Volume 6, 2, Agustus 2019| 33 
tersebut aya nu ngageugeuh (ada yang menjaga) yaitu seekor naga, konon bila ada yang mengganggu ketengangan atau merusak hutan maka naga tersebut akan keluar dan marah.

Masyarakat yang mempertahankan hutan sebagai bagian dari kehidupan mereka, akan dilindungi dengan beberapa cara yang kita anggap tidak masuk akal seperti jangan mengambil kayu di hutan karena akan menyebabkan marahnya mahluk ghaib penunggu hutan; masuk hutan tidak boleh bicaa kotor jika tidak ingin terkena musibah, dan larangan-larangan lain yang dapat menyebabkan kerusakan hutan. Perlindungan hutan seperti itu, merupakan salah satu perlindungan yang sampai sekarang dianggap efektif, sehingga kelestarian hutan tetap terjaga dibandingkan dengan adanya Undang-Undang dan sanksi hukum yang jelas bagi pelanggarnya, tetapi bagi masyarakat adat yang berhubungan dengan hutan menganggap bahwa hutan sebagai titipan dari karuhun (leluhur atau nenek moyang) yang harus dijaga apabila masih menginginkan kehidupannya terus berkelanjutan.

Selain itu nilai-nilai kearifan lokal hutan lindung Situ Lengkong adalah nilai keindahan hal tersebut nampak dari letak hutan lindung Situ lengkong yang berada di tengah-tengah danau, pohon-pohonnya yang rindang sehingga membuat udara di sekitar Situ Lengkong sangat sejuk, hal ini tentunya sangat mengurangi polusi udara sehingga daerah sekitar menjadi sehat dan bersih, ini sesuai dengan ajaran Islam bahwa kebersihan itu adalah sebagian dari Iman. Hal ini merupakan nilai kesehatan yang ada pada hutan Situ Lengkong.

Sumaatmadja (1986:83) menyatakan bahwa masalah lingkungan adalah masalah yang terjadi di lingkungan hidup manusia, yang mengancam ketentraman dan kesejahteraan manusia. Masalah lingkungan ini terjadi akibat adanya ketidakseimbangan antara komponen manusia (penduduk) dengan lingkungan yang menjadi penampung dan penjamin kehidupan manusia.

Lingkungan sangat penting bagi manusia. Segala sesuatu yang ada dilingkungan dimanfaatkan oleh manusia. Arti penting lingkungan bagi manusia menurut Herimanto \& Warno (2009:174) adalah: (1) Lingkungan merupakan tempat hidup manusia. Manusia hidup, berada, tumbuh, berkembang di atas bumi sebagai lingkungan; (2) Lingkungan memberikan sumber-sumber kehidupan manusia; (3). Lingkungan mempengaruhi sifat, karakter, dan prilaku manusia yang mendiaminya; (4) Lingkungan memberikan tantangan bagi kemjuan peradaban manusia; dan (5) Manusia memperbaikai, mengubah bahkan menciptakan lingkungan untuk kebutuhan dan kebahagiaan hidup.

Upaya untuk menumbuhkan kesadaran akan lingkungan yaitu melalui pendidikan ecopedagogy. Seperti halnya yang diungkapkan Supriatna (2011:68) berikut ini:"ecopedagaogy dapat diterjemahkan sebagai pendekatan dan proses pembelajaran untuk membentuk pengetahuan, sikap, watak dan keterampilan dapa para siswa yang selaras dengan gerakan green living. Dalam pendekatan tersebut dilakukan proses pembelajaran untuk memberikan pemahaman tentang keterbatasan sumber daya alam serta keterampilan yang diperlukan untuk memecahkan masalah tersebut".

Volume 6, 2, Agustus 2019 | 34 
Pembelajaran sejarah berbasis ecopedagogy bertujuan untuk menyiapkan peserta didik memiliki kompetensi atau kecerdasan ekologis. Kecerdasan yang dimaksud adalah berupa pemahaman tentang pembangunan berkelanjutan, pemahaman tentang semakin terbatasnya sumber daya alam, kemampuan beradaptasi atau hidup selaras dengan lingkungan yang menjunjung tinggi keadilan demi menyiapkan generasi yang akan datang yang akan dihadapkan pada persoalan-persoalan ekologis (Supriatna, 2012:180).

Melalui pendekatan ecopedagogy tersebut kemudian diintegrasikan dalam pembelajaran sejarah dengan bentuk pengembangan perilaku peduli pada lingkungan, yang kemudian disebut green behavior. Green behavior adalah tindakan penyelamatan bumi yang saat ini sudah mengalami pemanasan global akibat dari ulah manusia itu sendiri. Saat ini daya dukung bumi sudah sangat berkurang karena eksploitasi besar-besaran oleh manusia dalam tema pembangunan. Hutan semakin gundul, pohon-pohon yang mampu menyerap debu dan menahan air semakin berkurang. Berawal dari menjaga lingkungan sekolah yang bersih dan dapat berperilaku ramah terhadap lingkungan.

Green behavior bisa dimaknai sebagai suatu prilaku yang tindakannya didasari oleh suatu nilai, norma dan aturan yang mengutamakan kepedulian terhadap lingkungan. Green behavior inilah yang akan coba peneliti teliti pada siswa Sekolah Menengah Atas (SMA) melalui pembelajaran sejarah.

Sehubungan dengan etika lingkungan, Soerjani dkk (1987:15) mengemukakan bahwa etika lingkungan merupakan petunjuk atau perilaku praktis manusia dalam mengusahakan terwujudnya moral lingkungan, dengan etika lingkungan kita tidak saja mengimbangi hak dengan kewajiban terhadap lingkungan, tetapi etika lingkungan juga membatasi tingkah laku dan upaya untuk mengendalikan berbagai kegiatan agar tetap berada dalam batas kepentingan hidup kita.Melalui etika lingkungan sehingga hutan akan tetap terjaga dan terpelihara kelastariannya. Karena itu, etika lingkungan yang dijalankan oleh masyarakat adat melalui tradisi sebagai warisan budaya. Dengan demikian, bahwa etika lingkungan yang terbentuk di dalam kehidupan sebagai hasil dari kebudayaan dianggap memiliki nilai yang tinggi, sehingga harus dijalankan. Dalam hal ini etika lingkungan dapat dimasukkan ke dalam sistem nilai budaya Menurut Daeng (2000:46) sistem nilai budaya menjiwai semua pedoman yang mengatur tingkah laku warga pendukung kebudayaan yang bersangkutan. Pedoman tingkah laku itu adalah adat istiadat, sistem normanya, aturan etikanya, aturan moralnya, aturan sopan santunnya, pandangan hidup, ideologi pribadi.Nilai budaya yang ada pada manusia yang berhubungan dengan lingkungan terutama hutan, sistem nilai budaya tersebut akan berkembang apabila hutan tersebut dirasakan daya dukungnya sudah semakin menurun (hutan mulai rusak) dan berasa pada batas yang dianggap dapat menggoyahkan kehidupan mereka, maka diperlukan usaha untuk menjaga perilaku masyarakat adat yang dapat merugikan lingkungan dan manusia lainnya. Dengan demikian, kearifan lokal sebagai usaha untuk menjaga dan melindungi hutan yang dimiliki oleh masyarakat adat sebagai bentuk dari etika lingkungan.

Volume 6, 2, Agustus 2019| 35 
Dengan demikian melalui kearifan lokal dalam menjaga hutan lindung Situ Lengkong cukup melalui amanat leluhur (tabu) yang harus dilaksanakan secara turun temurun ternyata ampuh dan mereka tidak berani untuk melanggarnya. Dari rasa takut akan hukuman jika melanggar amanat leluhur (tabu) tersebut, menjadikan hutan tetap terjagaa kelestariannya. Karena itu, masyarakat adat yang menjaga hutan lindung tampaknya kita harus bercermin dari mereka, apalagi kehidupan kita penuh dengan Peraturan dan Undang-Undang yang tegas beserta sanksi hukum ternyata tidak mampu untuk menjaga hutan walaupun dianggap sebagai milik negara.

Kearifan lokal dapat bersumber dari kebudayaan masyarakat dalam suatu lokalitas tertentu. Dalam perspektif historis, kearifan lokal dapat membentuk suatu sejarah lokal. Sebab kajian sejarah lokal yaitu studi tentang kehidupan masyarakat atau khususnya komunitas dari suatu lingkungan sekitar tertentu dalam dinamika perkembangannya dalam berbagai aspek kehidupan. Wijda dalam (Koentjaraningrat, 2005). Awal pembentukan kearifan lokal dalam suatu masyarakat umumnya tidak diketahui secara pasti kapan kearifan lokal tersebut muncul. Pada umumnya terbentuk mulai sejak masyarakat belum mengenal tulisan (praaksara). Tradisi praaksara ini yang kemudian melahirkan tradisi lisan.

Sebagai contoh nilai kearifan lokal yang dimiliki oleh suatu masyarakat khusunya masyarakat Panjalu merupakan sumber pembelajaran yang sangat penting di tengah pengaruh budaya global yang semakin kuat. Kearifan lokal ini penting diangkat dalam pembelajaran sejarah seperti pendapat Atmodjo (1986: 37; Bab 1: 8), bahwa "kearifan lokal merupakan kemampuan penyerapan kebudayaan asing yang datang secara seliktif, artinya disesuaikan dengan kondisi dan suasana setempat". Kearifan ini juga sangat mumpuni dalam menangkal budaya negatif globalisasi yang berupa perusakan lingkungan. Dengan memasukksn kearfian lokal termasuk kearifan lingkungan Hutan Lindung Situ Lengkong, peserta didik akan mewarisi nilai luhur tersebut dalam kehidupan sehari-hari. Melalui pendidikan sejarah-lah pewarisan budaya ini efektif dilakukan. Nilai kearifan lokal ini sangat layak diimplementasikan sebagai sumber pembelajaran sejarah. Hal ini sesuai dengan pendapat Susilo (2008: 161) bahwa "penting untuk melembagakan kembali (reinstitusionalisasi) kearifan-kearifan lokal tradisional karena ia membantu penyelamatan lingkungan".

\section{Analisis Pelaksanaan Pembelajaran Sejarah di SMKN I Panjalu dalam Mengembangkan Green Behavior Peserta Didik dengan Memanfaatkan Hutan Lindung Situ Lengkong}

Ada beberapa aspek dalam sistem pembelajaran dapat menjadi pendukung keberhasilan peserta didik dalam belajar. Peneliti dalam melakukan observasi terhadap pembelajaran sejarah di SMKN I Panjalu dengan nilai-nilai kearifan lokal hutan lindung Situ Lengkong dalam mengembangkan green behavior peserta didik, melakukan identifikasi terhadap lingkungan eksternal dan lingkungan internal yang dimiliki oleh SMKN 1 Panjalu sebagai bagian dari masyarakat. Tujuannya adalah untuk mengetahui sumber-sumber pendukung dan sumber-sumber penghambat pembelajaran secara holistik, untuk mempermudah

Volume 6, 2, Agustus 2019 | 36 
peneliti menganalisis pembelajaran sejarah yang menyertakan pembelajaran sejarah lokal yang berasal dari lingkungan sekitar masyarakat.

Pembelajaran juga dapat dipandang sebagai suatu proses, dimana guru sejarah harus dapat menyelenggarakan proses pembelajaran agar siswa dapat belajar. Menurut Komalasari (2011:3) lebih lanjut, proses pembelajaran yang dilakukan guru dalam memberikan fasilitator siswa belajar adalah dengan memperhatikan proses pembelajaran, yang meliputi: (1) Persiapan, dimulai dengan merencanakan program pengajaran tahunan, program semester dan penyusunan persiapan mengajar (lesson plan) berikut penyiapan perangkat pelengkapnya yang meliputi alat peraga dan alat-alat evaluasi, penggunaan bukubuku sumber penunjang, alat-alat peraga pembelajaran, tidak luput dari perhatian guru; (2) melaksanakan kegiatan pembelajaran sebagai lanjutan persiapan yang telah dilakukan oleh guru. Struktur dan situasi pembelajaran yang diwujudkan guru dengan menggunakan pendekatan, strategi dan metode yang sudah dipilih dan sudah dirancang penerapannya, memberikan pelayanan kepada siswa secara optimal; (3) menindaklanjuti pembelajaran yang telah dikelola guru untuk dapat memberikan pengayaan (enrichment) dan dapat pula memberikan bantuan kepada siswa yang mengalami kesulitan belajar.

Guru sejarah dituntut keprofesionalannya dalam mendesain proses belajar mengajaran sebagai bagian dari kompetensi guru sejarah. Ini merupakan unsur yang sangat penting sebagai salah satu faktor penunjang yang mempengaruhi keberhasilan pembelajaran peserta didik. Selain mendesain proses pembelajaran, gurupun harus mampu melaksanakan proses pembelajaran dan mengevaluasi yang harus dilakukan secara sistematis agar menghasilkan tujuan-tujuan pembelajaran secara efektif dan efisien.

Peran penting nilai-nilai kearifan lokal hutan lindung Situ Lengkong dalam mengembangkan green behavior sebagai sumber belajar sejarah lokal, dapat memberikan pemahamanan materi pelajaran sejarah yang berasal dari buku teks dengan lingkungan terdekat siswa. Sebenarnya, siswa dapat mengaitkan materi pembelajaran yang ada pada buku teks dengan materi pembelajaran berbasis kontekstual. Blanchard (2001) dan Berns \& Erickson (2001:2) mengemukakan bahwa:

"Contextual teaching and learning is a conception of teaching and learning that helps teachers relate subject matter content to real world situations; and motivated students to make connections between knowlwdge and its aplications to their lives as family members, citizens and workers and engage in the hard work that learning requires."

Berdasarkan hasil observasi dan wawancara yang dilakukan peneliti di SMKN I Panjalu, guru mata pelajaran sejarah memberikan inovasi pembelajaran dengan menggunakan pendekatan kontekstual. Guru mata pelajaran sejarah memberikan kesempatan kepada peserta didik untuk memahami lingkungan sekolahnya dengan pembelajaran sejarah yang dipelajari dari buku teks sejarah sehingga peserta didik lebih memahami keterkaitan antara apa yang dipelajari dengan kenyataan yang ada di lingkungan. Guru sebagai fasilitator harus biasa memotivasi peserta didik dalam belajar sejarah, melalui penemuan materi 
pembelajaran bermakna bagi dirinya, sehingga mendorong siswa untuk dapat menemukan dan memiliki pengetahuan berdasarkan kemampuan yang dimilikinya, seperti pendapat Vygotsky tentang mengkonstruksi-sosial yang berkaitan dengan teori hukum genetik tentang perkembangan (genetic law development) menjelaskan bahwa "kemampuan seseorang tumbuh dari lingkungan sosial dan dari dalam diri individu".

Berdasarkan pendapat Vygotsky, lingkungan sosial siswa sangat berperan dalam pembentukan pengetahuan individu. Oleh karena itu pembelajaran lokalitas siswa dapat dijadikan sebagai sumber belajar sejarah, lebih lanjut lokalitas wilayah seperti desa, kecamatan, kabupaten, kota kecil dan lain lain, kesatuan wilayah serta unsur-unsur institusi sosial dan budaya yang berada di suatu lingkungan itu seperti keluarga, pola pemukiman, mobilitas penduduk, kegotongroyongan, pasar, teknologi pertanian, lembaga pemerintahan setempat, perkumpulan kesenian, monumen dan lain-lain, Sudrajat dalam http://akhmadsudrajat. files.wordpress. com/2008/07/, sangat relevan digunakan guru sebagai sumber belajar sebagai bagian dari sejarah lokal.

Lokalitas siswa umumnya sebagai masyarakat yang berada dekat dengan hutan lindung Situ lengkong, ternyata siswa tidak dapat memahami keterkaitan antara materi pembelajaran yang selalu berpedoman pada buku teks sejarah yang banyak mengungkapkan fakta, peristiwa yang sangat banyak. Pembelajaran sejarah di sekolah seakan tidak memiliki keterkaitan dengan lingkungan dimana siswa tinggal. Melalui kreativitas guru sejarah yang profesional yang sekaligus berkompeten, mengemas desain pembelajaran sejarah berkontekstual yang menghasilkan siswa berwawasan lingkungan masyarakat sekitar (Mulyana \& Gunawan, 2007:11).

Berdasarkan hasil observasi dan wawancara peneliti, guru pelajaran sejarah telah melakukan langkah-langkah yang mesti dilakukan sebagai guru yang profesional, langkah-langkah guru adalah yaitu: (1) Guru telah mendesain tujuan pembelajaran sejarah lokal sesuai silabus pembelajaran sejarah dan dibuat oleh Bapak Ohim Hadia Natasasmita S.Pd sebagai guru mata pelajaran sejarah di kelas X SMKN I Panjalu; (2) Guru membuat silabus dengan berpedoman pada KTSP, kemudian dijabarkan dengan SK/KD, RPP dengan indikator-indikator, tujuan pembelajaran sejarah, materi pembelajaran, pendekatan, strategi dan metode pembelajaran, evaluasi pembelajaran dan tindak lanjut pembelajaran seperti remedial dan pengayaan.

Peneliti mengobservasi desain pembelajaran guru yang mengaitkan potensi lokal lingkungan peserta didik sesuai dengan KTSP. Peneliti melihat dokumen yang dimiliki guru mata pelajaran sejarah seperti KTSP yang menjadi landasan guru membuat rencana pembelajaran sejarah lokal dengan memanfaatkan nilainilai kearifan lokal Hutan Lindung Situ Lengkong sebagai sumber belajar sejarah dalam rangka mengembangkan green behavior peserta didik, guru memasukkan keterkaitan silabus dengan KTSP pada pelajaran Sejarah kelas X semester satu di satuan pendidikan SMA dengan Kompetensi Inti (KI) "Menghayati dan mengamalkan perilaku jujur, disiplin, tanggung jawab, peduli (gotong royong, kerja sama, toleran, damai), santun, responsif dan pro aktif dan menunjukkan

Volume 6, 2, Agustus 2019 | 38 
sikap sebagai bagian dari solusi atas berbagai permasalahan dalam berinteraksi secara efektif dengan lingkungan sosial dan alam serta dalam dalam menempatkan diri sebagai cerminan bangsa dalam pergaulan dunia.". Sedangkan KD-nya adalah: "Menganalisis berdasarkan tipologi hasil budaya pra aksara Indonesia termasuk yang berada di lingkungan terdekat".

Peneliti melihat kreativitas guru mata pelajaran sejarah untuk dapat mendesain materi pembelajaran yang ada pada buku teks pelajaran sejarah dengan kegiatan pembelajaran yang akan dilakukan, yaitu melalui metode diskusi yang dipadukan dengan beberapa metode seperti ceramah, tanya jawab, pemberian tugas, dan pengalaman lapangan.

Pembelajaran kontekstual didasarkan pada hasil penelitian Dewey (1916) yang menyimpulkan bahwa siswa akan belajar dengan baik jika apa yang dipelajari terkait dengan apa yang telah diketahui dan dengan kegiatan atau peristiwa yang akan terjadi di sekelilingnya. Pembelajaran ini menekankan pada daya pikir yang tinggi, transfer ilmu pengetahuan, mengumpulkan dan menganalisis data, memecahkan masalah-masalah tertentu baik secara individu maupun kelompok. Dalam konteks ini siswa perlu mengerti apa makna belajar, manfaatnya, dalam status apa mereka dan bagaimana mencapainya. Dengan ini siswa akan menyadari bahwa apa yang mereka pelajari berguna sebagai hidupnya nanti. Sehingga, akan membuat mereka memposisikan sebagai diri sendiri yang memerlukan suatu bekal yang bermanfaat untuk hidupnya nanti dan siswa akan berusaha untuk meggapainya.

Nilai kearifan lokal sebagai sumber belajar dapat menjadikan proses pembelajaran lebih mudah. Menurut teori kognitif bahan ajar itu harus disajikan dari yang sederhana menuju yang lebih kompleks. Bahan ajar juga harus disajikan dari yang paling dekat menuju yang paling jauh. Hal ini menunjukan bahwa sebelum mengkaji bahan yang bersifat global terlebih dahulu peserta didik harus diperkenalkan dengan bahan ajar yang paling dekat dengan lingkungannya.

Berdasarkan kajian di atas, tujuan pendidikan sejarah itu tidak hanya berorientasi pada kecerdasan intelektual peserta didik semata, tetapi beragam kecerdasan yang dimiliki sebagai aspek kemanusiaannya. Dia harus cerdas dalam emosi, dalam sikap,dalam bekerja keras, dalam kehidupan berbangsa dan dalam kehidupan umat manusia. Pendidikan sejarah tidak perlu membatasi dirinya pada kaedah-kaedah ilmu semata yang juga pada dasarnya memiliki aspek etika dan aspek lainnya (Hasan,2012:25).

\section{SIMPULAN}

Penelitian ini berisi nilai-nilai kerifan lokal Situ Lengkong yang berkembang dari mitos dan tabu yang ada di hutan Situ Lengkong yang masih dipegang teguh oleh masyarakat Panjalu, yaitu adanya larangan untuk tidak sembarangan masuk ke hutan tersebut, larangan menebang pohon dan mengambil kayu bakar yang ada di hutan dan larangan menggangu habitat yang ada di dalam dan sekitar hutan. Jika semua larangan itu dilanggar maka akan mendapat musibah atau malapetaka, maka dari hal mitos dan tabu itu dapat diartikan sebagai usaha menjaga kelestarian hutan Situ Lengkong yang diwariskan para leluhur.

Volume 6, 2, Agustus 2019 | 39 
Berdasarkan uraian hasil penelitian dan pembahasan mengenai nilai-nilai kearifan lokal hutan lindung Situ Lengkong dalam mengembangkan green behavior peserta didik melalui pembelajaran sejarah di SMKN 1 Panjalu dapat penulis simpulkan sebagai berikut:

1. Kearifan lokal masyarakat Panjalu yang memiliki orientasi terhadap masalah lingkungan sudah terbukti secara historis. Hal tersebut tercermin dalam tradisi dan mitos-mitos yang dimaknai oleh masyarakat Panjalu sebagai upaya untuk melestarikan lingkungan dalam rangka suistainable development. Berkaitan dengan penjagaan kelestarian hutan lindung Situ Lengkong ada hal-hal tabu yang ditaati oleh masyarakat setempat seperti larangan menebang pohon, mengambil hasil hutan, berbicara sembarangan, dan berperilaku tidak senonoh, jika semua tabu itu dilanggar maka siapapun akan mendapatkan malapetaka. Bahkan jika penebangan pohon dilakukan oleh banyak orang akan menimbulkan bencana bagi masyarakat. Bila dikaji secara logis baik mitos maupun tabu dapat dimaknai sebgai bentuk penjagaan dan pemeliharaan kelestarian hutan.

2. Implementasi nilai-nilai kearifan lokal yang mengembangkan green behavior peserta didik dalam pembelajaran sejarah di SMA Negeri 1 Lumbung, guru sudah memiliki pengetahuan yang memadai tentang nilai-nilai kearifan lokal Hutan Lindung Situ Lengkong dalam upaya pengembangan green behavior walaupun tidak nampak tersurat dalam kurikulum. Implementasi dalam pembelajaran sejarah yaitu dengan cara merangsang kemapuan berpikir kritis peserta didik dengan pertanyaan-pertanyaan mengenai berbagai mitos dan tabu Hutan Lindung Situ Lengkong. Selain itu guru tidak hanya menyajikan nilainilai kearifan lokal melalui pengintgrasian kedalam materi sejarah namun guru mengajak siswa untuk melakukan tindakan nyata dalam upaya mewujudkan green behavior.

\section{DAFTAR PUSTAKA}

Atmodjo, M.M.S.K. (1986). Pengertian Kearifan Lokal dan Relevansinya dalam Moderenisasi. Dalam Ayat Rohendi Penyunting (1986). Kepribadian Budaya Bangsa (Local Genius). Jakarta: DPJ.

Daeng, Hans. (2000). Manusia, Kebudayaan dan Lingkungan. Yogyakarta: Pustaka Pelajar.

Hasan, SH. (2012). Pendidikan Sejarah Indonesia: Isu dalam Ide dan Pembelajaran. Bandung: Rizqi Press.

Hasan, SH. (2012). Pendidikan Sejarah Indonesia: Isu Dalam Ide dan Pembelajaran. Bandung. Rizqy Perss.

Herimanto, W. 2009. Ilmu Sosial dan Budaya Dasar. Jakarta: Bumi Aksara. Koentjaraningrat. (1990). Pengantar Ilmu Antropologi. Jakarta; Rineka Cipta.

Komalasari, K. (2010). Pembelajaran Kontekstual. Bandung: Remaja Rosdakarya.

Mutakin, A. (2005). Nilai-NilaiKearifan Adat dan Tradisi di Balik Simbol (Totem) Kuda Kuning. Bandung; FPIPS-UPI.

Saini, K.M. (2004). Krisis Kebudayaan (Pilihan 10 Essai). Bandung: Kelir.

Volume 6, 2, Agustus 2019 | 40 
Supriatna, N. (2011). Pengembangan Pendidkan Karakter Melalui Green Curriculum dan Ecopedagogy dalam Pembelajaran IPS, Prosiding Konvensi Nasional Pendidikan IPS Ke-1 : FPIPS-UPI: Bandung.

Supriatna, N. (2012). "Ecopedagogy dan Green Curriculum dalam Pembelajaran Sejarah". Pendidikan Sejarah untuk Manusia dan Kemanusiaan: Refleksi Perjalanan Karir Akademik Prof. Dr. H. Said Hamid Hasan, MA. Jakarta: Bee Media Indonesia.

Sutarto Ayu. (2006). Kearifan Lokal dan Perubahan Lingkungan Kasus Kampung Naga, Badui, Damin dan Tengger; Kumpulan Makalah.

Sumaatmadja, N. (1986). Manusia Dalam Konteks Sosial Budaya dan Lingkungan Hidup. Bandung: Alfabeta.

Soerjani, M dkk. (1987). Lingkungan Sumber Daya Alam dan Kependudukan dalam pembangunan. Jakarta: Universitas Indonesia Press.

Tn_. Hutan Lindung [Online]. Tersedia: http://id. wikipedia. org/wiki/ Hutan lindung (23 April 2013). 